\title{
Michel de Montaigne, Lettere. Con testo originale e traduzione a fronte
}

\section{Sabine Lardon}

\section{(2) OpenEdition}

\section{Journals}

Édition électronique

URL : http://journals.openedition.org/studifrancesi/3700

DOI : 10.4000/studifrancesi.3700

ISSN : 2427-5856

Éditeur

Rosenberg \& Sellier

\section{Édition imprimée}

Date de publication : 1 décembre 2012

Pagination : 556

ISSN : 0039-2944

\section{Référence électronique}

Sabine Lardon, "Michel de Montaigne, Lettere. Con testo originale e traduzione a fronte », Studi Francesi [En ligne], 168 (LVI | III) | 2012, mis en ligne le 30 novembre 2015, consulté le 05 mars 2021. URL

http://journals.openedition.org/studifrancesi/3700 ; DOI : https://doi.org/10.4000/studifrancesi.3700

Ce document a été généré automatiquement le 5 mars 2021.

\section{cc) $(1) \odot$}

Studi Francesi è distribuita con Licenza Creative Commons Attribuzione - Non commerciale - Non opere derivate 4.0 Internazionale. 


\title{
Michel de Montaigne, Lettere. Con testo originale e traduzione a fronte
}

\author{
Sabine Lardon
}

\section{RÉFÉRENCE}

MICHEL DE MONTAIGNE, Lettere. Con testo originale e traduzione a fronte, a cura di Alberto FRIGO, Firenze, Le Monnier Università, 2010, pp. 183.

1 Alberto Frigo livre ici une élégante édition bilingue de trente-six lettres de Montaigne. Le texte français est donné en page paire, dans le respect de la graphie et de la ponctuation originales. Une traduction italienne est proposée en vis-à-vis en page impaire, où des notes de bas de page viennent éclairer essentiellement l'identité des personnages ou, de manière plus ponctuelle, une date, un événement ou un aspect linguistique (le sens d'un mot, un problème de traduction ou une citation). En l'absence de bibliographie, «l'avvertenza» (p. 65) fournit les principales indications bibliographiques. En outre, le texte est précédé d'une importante introduction (pp.1-62) qui envisage successivement les positions de Montaigne concernant le protocole épistolaire (formules d'adresse et de valédiction), la place de La Boétie dans ces lettres et sa correspondance en tant que magistrat et homme politique. Ce volume fournit ainsi non seulement une traduction italienne de la correspondance de Montaigne, mais encore une belle édition richement introduite (complétée par un index des noms propres). 